\title{
PATTERNS OF EVOLUTION IN NORTH AMERICAN NEOGENE MAMMALS
}

JACOBS*, Louis, Shuler Museum of Paleontology, Southern Methodist University, Dallas, TX 75275, U.S.A., and JANIS, Christine, Division of Biology and Medicine, Brown University, Providence, RI 02912, U.S.A.

The Neogene of North American represents a time of climatic change from an initially warm, non-arid climate to one with the development of increasing aridity, with warming temperatures through the early part and fluctuating (but basically cooler) temperatures through the later part. This reflects the classic story of a vegetational change from woodland to savanna and eventually to prairie. Note that the transition to true savanna in the Late Miocene was considerably earlier than the first savannas in the Pliocene of the Old World. The evolutionary trends in mammals reflect these climactic and vegetational changes.

Some general broad trends are as follows: the replacement of terrestrial and subfossorial moles and geomyid rodents with more specialized fossorial ones; a decrease in the diversity of brachydont rodents and an increase in the diversity of hypsodont ones (including saltatorial forms), and a late Neogene diversification of microtines and deer mice; a decline in the diversity of tree squirrels and terrestrial beavers, and an increase in diversity of ground squirrels and aquatic beavers; the replacement of carnivores belong to more archaic families by more modern types; taxa and an increase in body size, leg length, and hypsodonty in most ungulate taxa, including oreodonts, protoceratids, camelids, antilocaprids, rhinos and equine horses although a couple of taxa show an apparent reversal of these trends: dromomerycids (cervoids) and some anchitherine horses show other morphological changes that suggest progressively more woodland-adapted (rather than savanna-adapted) forms. Tapirs and (to a lesser extent) peccaries seem little affected by the Neogene changes, and persist until the Recent.

The Neogene was also punctuated by immigration events (primarily from Asia) and extinctions. The start of the Neogene shows surprisingly little change, with many Paleogene "holdovers": some new forms appear as either the result of evolution in situ (e.g. equine horses and osteoborine dogs) or as immigrants (e.g. chalicotheres and hemicyonine "dog bears"). The initial major immigrations are during the late Early Miocene, marked by the Asian appearances of true felids (replacing the "false sabertooths" or nimravids), pecoran ruminants (replacing the hypertragulids), more derived rhinos (replacing the diceratherine rhinos), neomustelids and procyonids. Archaic suoids such as anthracotheres and entelodonts become extinct at this time, and only the more derived ticholeptine oreodonts survive this period. The start of the Middle Miocene is notable for the appearance of proboscideans and deer mice. The Late Miocene sees the decline and eventual disappearance of hedgehogs, archaic carnivores (hemicyonine bears and amphicyonids), most browsing ungulates (oreodonts, protoceratids, many camelids, anchitherine horses, dromomerycids, merycodontine antilocaprids, hornless ruminants, chalicotheres, bunodont gomphotheres), and rhinos. New taxa appearing including ursine bears (immigrants), oversized camels and more derived gomphotheres (in situ evolution). The Pliocene marks a new wave of immigration: microtines, hyenas, true saber-tooths, and cervids come in from Asia; ground sloths (two families appearing in the Late Miocene), glyptodonts, armadillos and capybaras come in from South America. Most mammals that survived the end Miocene extinctions persist, but for many of them (such as horses, camels and antilocaprids) the generic diversity is greatly reduced. 